\title{
Historical Demography and Historical Sociolinguistics: The Role of Migrant Integration in the Development of Dunkirk French in the 17th Century
}

\author{
Remco Knooihuizen ${ }^{\mathrm{a}}$, Dan Dediu ${ }^{\mathrm{b}}$ \\ a) Lecturer in English, Rijksuniversiteit Groningen, Faculteit der Letteren, \\ Postbus 916, 9700 AS Groningen, The Netherlands (corresponding author) \\ r.m.knooihuizen@rug.nl
}

b) Research Staff, Language and Genetics Department, Max Planck Institute for Psycholinguistics, Nijmegen, The Netherlands dan.dediu@mpi.nl

\begin{abstract}
Widespread minority language shift in Early Modern Europe is often ascribed to restrictive language policies and the migration of both majority- and minority-language speakers. However, without a sociohistorically credible account of the mechanisms through which these events caused a language shift, these policies lack explanatory power. Inspired by research on 'language histories from below,' we present an integrated sociohistorical and linguistic account that can shed light on the procresses taking place during a case of language shift in the 17th and 18th centuries. We present and analyze demographic data on the immigration and integration of French speakers in previously Dutch-speaking Dunkirk in this period, showing how moderate intermarriage of immigrants and locals could have represented a motive and a mechanism for language shift against a backdrop of larger language-political processes. We then discuss the modern language-shift dialect of Dunkirk in comparison with different dialects of French. The linguistic data suggests a large influence from the dialects of migrants, underlining their role in the language shift process. The combination of sociohistorical and linguistic evidence gives us a better understanding of language shift in this period, showing the value of an integrated 'from below' approach.
\end{abstract}

\section{Keywords}

French; historical sociolinguistics; language shift; migration; demography

\section{Introduction}

The Early Modern period, roughly between the Protestant Reformation and the French Revolution, was a period of significant improvement in the social status of vernacular languages. Burke (2004), for example, sketches some of 
the social developments that allowed many European vernaculars to take over from Latin as the preferred language in the domains of religion, politics, administration and law, science and education, and the belles lettres. Burke's account gives very little attention to the fact that not all vernacular languages came out victorious: the Early Modern period is also the time during which 'minority languages' in their present meaning emerged—languages that did not attain the status of Latin, became subordinate to other vernaculars, and in some cases even died out.

A factor that is frequently mentioned in individual histories of minority languages in the Early Modern period as contributing to these languages' demise and their speakers' shift to the various majority languages is the existence of proscriptive language policies. These are exemplified by legislation such as the Act of Union between England and Wales (1536), which stipulated that knowledge of English was necessary to hold any office (Jenkins et al., 1997: 62-64); the French Édit de Villers-Cotterêts (1539), which required that all official government correspondence and documentation be in French (Boulard, 1999; Martel, 2001); the Statutes of Iona (1609) in Scotland, which ordered chiefs of Gaelic-speaking Highland clans to send their sons to be educated in the Lowlands, to learn Protestantism and English (Withers, 1984: 29); and the Brandenburg-Prussian elector Friedrich Wilhelm's Dezemberreskript (1667), banning preaching in Sorbian and ordering all Sorbian writing to be destroyed (Kunze, 1999). This legislation did, of course, not benefit minority languages and was definitely a factor in setting a disadvantageous scene, but demographic and linguistic evidence suggests that language policies alone were not the decisive factor in early modern language shift and death.

An account that stresses the role of language policies is an example of language history 'from above.' However, especially in the case of often invisible minority-language speakers, we believe more can be gained from an approach 'from below,' which focuses on average everyday language users rather than on the language use of political and cultural elites or on larger social and political structures (see Elspaß, 2005: 12-20 for a discussion of language history writing 'from above' and 'from below'; note that the terms 'above' and 'below' neither denote class distinctions nor refer to the traditional Labovian concept of language change above or below the level of conscious awareness). How does the Act of Union explain that people without any ambition of a government office shifted from Welsh to English? And if Villers-Cotterêts forced Occitan speakers to use French in official documents, why would they use spoken French in their everyday private lives? We need to investigate other contributing factors to begin writing an explanation of early modern minoritylanguage shift that fits a language history from below as well as above. With the help of an exploratory case study, we aim to show that a novel combination 
of different approaches to sociohistorical and linguistic data combined can provide an account of language shift in the past that fits both the perspective of everyday language users and that of language policies and social structures.

In this paper we will focus on the role of migration in language shift. A substantial immigration of majority-language speakers appears to have preceded, or at least coincided with, the onset of large-scale language shift in a wide range of cases in the early modern period: Shetland Norn (Donaldson, 1983), Scottish Gaelic (Withers, 1988: 88-91), Manx (Broderick, 1999: 24), Cornish (Smith, 1947: 7-9), Irish (Mac Giolla Chríost, 2005: 93), Frisian (Vries, 2001: 608-612), Sorbian (Brankačk and Mětšk, 222-224, 284-288), and French Flemish (Ryckeboer, 2004: 27-28). ${ }^{1}$ If the majority-language migrants came to the minority-language area in large enough numbers, there would be no need for them - as speakers of a socially prestigious language - to acquire the minority language that was previously dominant in the area. Instead, it is the minority-language speakers that have to accommodate and acquire the majority language. If the immigrants are well integrated with the local population, this would be a mechanism through which the majority language could be introduced into the minority-language speakers' home sphere.

It is no new finding that migration can be a major contributing factor in language shift. In this paper, we aim to clarify some of the dynamics of how migration and language shift are linked. We do this by taking a two-pronged approach to a study of language shift in the town of Dunkirk in French Flanders, combining a historical demographic approach to immigration and integration of French speakers (Section 3) with a historical and quantitative linguistic approach to the language-shift dialect of French now spoken in Dunkirk (Section 4). We show that the linguistic and demographic data are consistent with each other, suggest how the language shift in Dunkirk may have proceeded, and finish with some concluding remarks about the impact of our findings (Section 5).

\section{Dunkirk}

Present-day Dunkirk is a harbor town of approximately 70,000 inhabitants on the North Sea coast of the French département Nord. It is the largest town in the area, known as the Westhoek 'Western Corner' of French Flanders, and like the region as a whole, has a history characterized by dynastic conquest. Previously in Burgundian, French and Spanish hands, the town was conquered by the

\footnotetext{
1) In particular in the cases of Scottish Gaelic (Withers, 1988: 312-313) and Sorbian, we can see emigration (not always entirely voluntary) of minority-language speakers to majority-language areas, where they had to find a place in majority-language social networks.
} 
English in 1657 and sold back to the French in 1662. The surrounding area came under French control in 1678.

French Flanders was traditionally a Dutch-speaking area, although centuries of cross-border contacts with French speakers had already caused the language border to slowly move northwards. The events of the mid-17th century saw the area annexed permanently to a country run by French speakers: Dutch had now become the minority language and French was the majority language. Note that 'majority' and 'minority' here are not defined in numerical terms, but along a power dimension; see, e.g., Allardt (1984). In French Flanders locally, for quite some time after the annexation, there may well have been more Dutch native speakers than French native speakers.

With the annexation, the Édit de Villers-Cotterêts (see above) applied to French Flanders now as well and was reinforced by a 1663 edict from Louis XIV, demanding that French be used in legal acts and that French-speaking clergy be appointed (Cabantous, 1983: 114). The regulations were successful in that Dutch had disappeared completely from church documents in Dunkirk by 1670 and French was used increasingly in, e.g., marriage contracts (Cabantous, 1983: 115). French, then, appears to have made rapid inroads in particular in the high-prestige domains of law and religion. Dutch, however, remained predominant in education (Trenard, 1972: 338) and was also a valued language for purposes of trade (Cabantous, 1983: 115).

The region's annexation to France triggered a significant migration into the area (Ryckeboer, 2004: 27) which caused a spectacular population growth. Dunkirk grew from about 5,000 inhabitants in 1662 to 10,000 in 1685 , and to 14,000 in 1706 (Goris, 2004: 332). The immigrants are likely to have been military or administrative personnel, or involved in the realization of infrastructural developments begun after the annexation, and many of them must have been French speakers (Cabantous, 1983: 73).

The language shift from Dutch to French may well have been underway for centuries, but such a massive immigration must have dealt a decisive blow to the position of Dutch in the town. For example, Thomason and Kaufman (1991: 122) posit that a majority-language (here: French) population making up about a third of the total population is unlikely to learn the minority language of an area. Communication between the two population groups must then take place in the majority language, which may contribute to triggering a language shift among the minority-language (here: Dutch) population. However, as language change is known to proceed through social networks, and segregated speech communities within a larger context can withstand language change for a long time (Milroy, 1987: 181-182), we need to consider the integration of immigrants into Dunkirk society to learn how that informs our knowledge of language shift in 17th-century Dunkirk. 
Although there is a sizeable body of work on the loss of Dutch from the Dunkirk area (e.g., Ryckeboer, 2000, 2002, 2004; Willemyns, 1997), the spread of French to Dunkirk has received remarkably little attention from local historians, and as a result is ill-understood (Cabantous, 1983: 114). Our study should be seen as a contribution to the writing of the story of this language spread, combining research methods from history, sociolinguistics and dialectology. Although we aim to show that this type of research can make a valuable contribution, we must also be aware that it only shows part of the picture. Local centers in recently annexed areas, like Dunkirk, functioned as gateways to the world outside France (Dupâquier et al., 1988: 93), and especially relevant contacts with other Dutch-speaking areas cannot be shown with our data. Moreover, urban populations, and urban migrants in particular, were very transient in this period (Dupâquier et al., 1988: 120). There is, however, no reason to believe that the patterns exposed in our study are not representative of larger-scale developments in the town. Finally, we focus specifically on the spread of French to Dunkirk, not on the complementary process of the loss of Dutch from the town (see also Section 4). Our findings are meant as an addition to previous research from an alternative perspective, not as a complete replacement of earlier views.

\section{Immigration and Integration}

The integration of immigrants can be charted by looking at intermarriage between different population groups. Marriage registers often survive and, as will be shown below, contain the information needed to do such a study, although especially in newly annexed areas such as 17th-century Flanders there may be considerable gaps in the record (Dupâquier et al., 1988: 101). Intermarriage is particularly relevant to language shift, as it is thought to be an important factor in the process (Paulston, 1986: 498-499): the access to and socialization in the majority language that is provided by intermarriage is a prerequisite for language shift.

\subsection{Previous Research}

Past studies of migration, both in a British and in a French historical context, have used data from marriage registers, although these studies have tended to focus more on the origins of immigrants than on their integration into their new community. It was found for both England (Millard, 1982) and Northern France (Lemercier and Rosental, 2000) that short-distance, 'local,' migration was much more frequent than longer-distance migration. Cross-referencing data from marriage registers with baptismal records, however, Pain and Smith 
(1984) claim that marriage registers may considerably underestimate personal mobility, showing immigrants as resident in a parish even though they were not born there. Bellingham (1990) found that this underestimation is particularly striking in periods of rapid population growth.

Studies by Stevens (1985) and Stevens and Swicegood (1987) examine the integration of migrants with a different ethnolinguistic background, albeit in a modern American rather than historical European context. Both studies show that linguistic assimilation, i.e. having English as the mother tongue, preceded the overall assimilation of an ethnolinguistic minority group through intermarriage.

This previous research suggests that an analysis of ethnolinguistic marriage patterns in 17th-century Dunkirk can shed light both on patterns of immigration and on the integration of French- and Dutch-speaking immigrants in the formerly predominantly Dutch-speaking area. If there is evidence of widespread intermarriage, we can draw the conclusion that immigrants are well integrated, and we can expect linguistic assimilation to occur (or to have occurred). Which of the groups undergoes language shift depends on the social circumstances; in the case of Dunkirk, it would be the local population shifting to the immigrants' language.

A previous study of the origins of migrants in Dunkirk based on marriage registers between 1770 and 1790 was reported in Cabantous (1983: 94). Cabantous found that approximately $34 \%$ of immigrants came from within $20 \mathrm{~km}$ of Dunkirk, $34 \%$ from the rest of the French Netherlands, $16 \%$ from elsewhere in France, and 16\% from the rest of Europe. The data for our study is a century older than that in Cabantous' investigation, and concerns the period immediately around the annexation. Our study further differs from the one by Cabantous in that we analyze migration patterns purely on the basis of distance, not political regions. In addition to geographical provenance, we test for a number of social factors, viz. language background, gender, previous marriage status, and literacy. This allows us to paint a more refined picture of the immigration and point to relevant social constraints on both migration and intermarriage.

\subsection{Sources and Data}

For our study, data was taken from parochial marriage registers in Dunkirk, available in the local archives. ${ }^{2}$ Because our primary interest in this exploratory

2) Dunkirk marriage registers were consulted in the Archives Municipales de Dunkerque in Dunkirk in August 2007. Copies were made from the available microfilms: 6Mi59 (registers 1647-1670), 6Mi60 (1670-1683) and 5Mi71 (1683-1703). 
study was with longitudinal developments, we collected a full year's worth of data at ten-year intervals between 1647 and 1697. This resulted in a data set of approximately 1000 marriages, spanning both sides of the French annexation of Dunkirk in 1662. The data was transcribed and analyzed off-site.

The available information in the marriage registers differs slightly from year to year. All entries in all years mention at least a date of marriage, the names of the bride and groom, their parishes of residence and previous marriage status (widow/widower or not), and the names of two to four witnesses. Additionally the entries may contain information on the partners' parishes of origin (1647 and 1657 only), or-if they were literate-their signature (1697 only). The entries are signed by a named priest.

This type of information allows for an analysis of migration patterns and of intermarriage between the two language groups, where language allegiance is assigned on the basis of names (see below). We correlate preferences for marriage partners with people's gender, previous marriage status, literacy, and immigration status; we clarify in our discussion why we think these factors may have been relevant in language shift.

We believe this data to be representative of Dunkirk in this period. The data is taken from marriage registers of the Catholic church, so we have no data on any Protestants that may have lived in the town. However, it appears that the Protestant population of Dunkirk peaked at some $8 \%$ shortly after the Reformation, and that there was no Protestant population to speak of in the 17th century. Protestants in Dunkirk were mostly foreigners; although some of them were Dutch, this is unlikely to bias the results of our analyses (Coornaert, 1970: 117, 230).

We assigned language allegiance (a more appropriate term than the common shorthand 'ethnicity') on the basis of names, especially surnames. This was done with the help of an etymological dictionary of surnames in the area (Debrabandere, 2003). Particular attention was paid to the form of the surname rather than solely its etymology. Any additional information given in the entries, such as the form of the first names in people's signatures or descriptions as miles gallus 'French soldier,' was taken into account.

Names are by no means an unambiguous indicator of language allegiance. By the period our study relates to, family names had mostly become fixed and were passed from a father to his children. In the case of language shift in earlier generations through migration or linguistic intermarriage, the fixed family name would still suggest the original language background rather than the language-shifted reality. Despite these problems, the loose links that do exist between a person's name and their language background have been recognized by earlier researchers and have been used in studies of modern (Levine, 1988; Mateos, 2007; Webber, 2007) and historical (Fellows-Jensen, 1968: esp. 


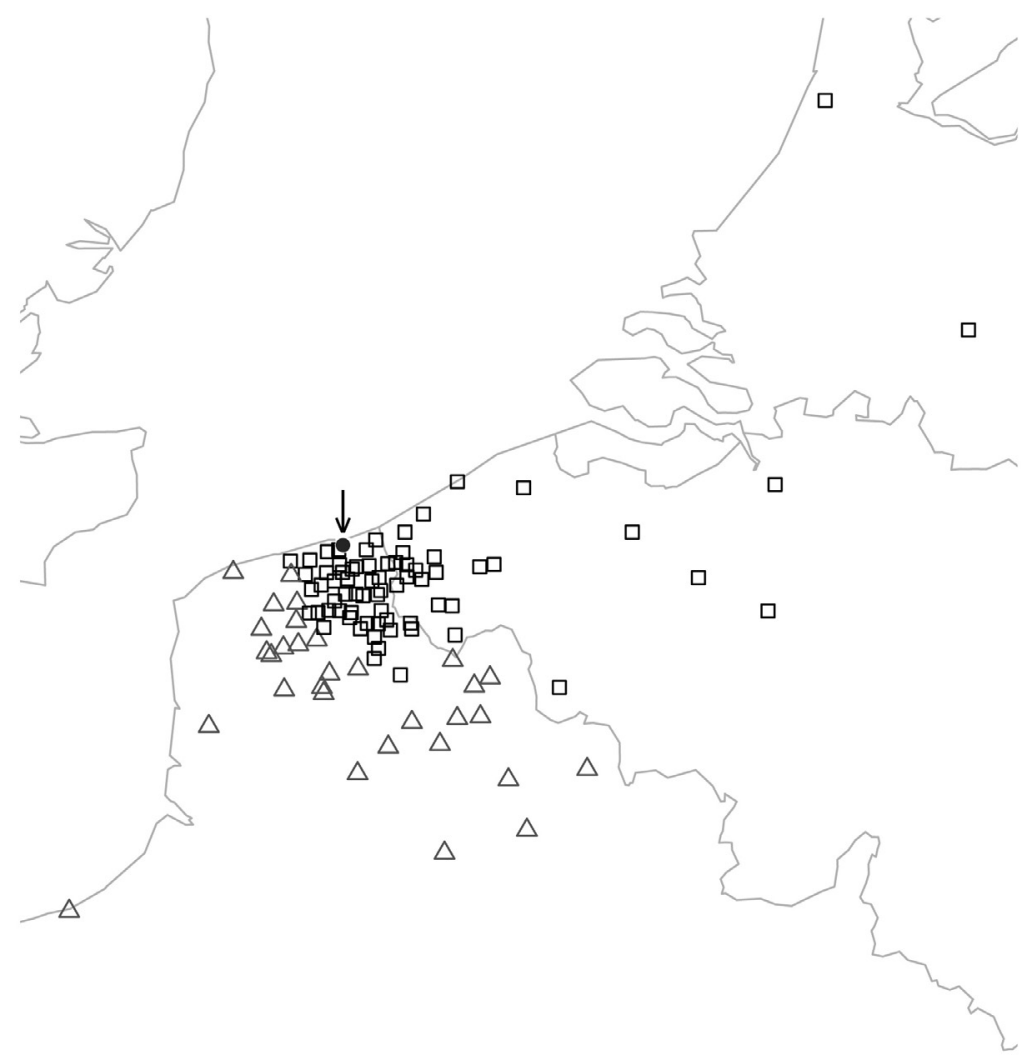

$\triangle$

$\triangle$

$\triangle$

Figure 1. Map of the origins of migrants to Dunkirk in 1647 and 1657, by language. 
xvi-xviii; Donaldson, 1983; Lomas, 2002: 179) societies. Similarly, in two studies concerning the same area and language-contact situation as ours, the frequency of Flemish family names in predominantly Francophone areas is used as a measure of migration from Flanders (Poulain and Foulon, 1981; Poulain et al., 2000). In such historical studies, names are often the only available clue to people's linguistic allegiance. Their use in this study is therefore out of necessity, but as these previous studies have obtained useful results with this type of data, we would like to attach a fair degree of credibility to this method.

\subsection{Migration Patterns}

We analyzed migration patterns for the years 1647 and 1657, the two years for which our data included people's parish of origin. ${ }^{3}$ Of 326 people in 163 marriages, the parish of origin could be positively identified with a present-day location for 286 individuals. We attempted to find those locations that were not immediately identifiable-place names were given in Latin or Latinized Dutch, while the same places are now known under a French name-by searching a map within a roughly $50 \mathrm{~km}$ radius from Dunkirk, the area where the majority of identified locations were situated. Therefore, there will be a slight bias in our data in favor of local residents and short-distance migrants. Figure 1 shows the map of the locations of the identified parishes of origin, classified by majority language of the parish (see Section 3.3.1 for details).

It is not a new idea that urban population growth in the early modern period depended to a significant degree on immigration from rural areas (see Sharlin, 1978, for a critical discussion). In Dunkirk, too, then, we would expect a large proportion of migrants among the population. The data on parishes of origin in the marriage register confirms this expectation (Table 1). In both 1647 and 1657 , at least as many people in the register are listed as having migrated to Dunkirk at some point, as were born there. Especially the proportion of nonlocal men in the 1647 data is striking (see also Suppl. Mat., Section 2.1). Such a population, where as much as $50 \%$ is not native to the town, is indicative of rapid growth.

\footnotetext{
3) In the interest of legibility, we restrict ourselves in the main text to the presentation and interpretation of relevant significant results. A detailed report on our statistical analyses can be found in the Supplementary Materials (see Section 6).
} 
Table 1. Locals and immigrants in the Dunkirk marriage register by gender and year. Note that the years given refer to date of marriage; immigrants migrated to Dunkirk an unknown amount of time previous to this year.

\begin{tabular}{lrcrccrr}
\multirow{2}{*}{ Gender } & Year(s) & Count & $\%$ & Count & $\%$ & Total \\
Male & 1647 & 23 & 29.5 & 55 & 70.5 & 78 \\
& 1657 & 22 & 38.6 & 35 & 61.4 & 57 \\
& Both & 45 & 33.3 & 90 & 66.7 & 135 \\
\multirow{5}{*}{ Female } & 1647 & 36 & 40.9 & 52 & 59.1 & 88 \\
& 1657 & 37 & 58.7 & 26 & 41.3 & 63 \\
& Both & 73 & 48.3 & 78 & 51.6 & 151 \\
\multirow{5}{*}{ Both } & 1647 & 59 & 35.5 & 107 & 64.5 & 166 \\
& 1657 & 59 & 49.2 & 61 & 50.8 & 120 \\
& Both & 118 & 41.3 & 168 & 58.7 & 286
\end{tabular}

\subsubsection{Migration Patterns by Language Background}

To begin our investigation of the links between migration and language shift, we tested whether migration patterns were different for immigrants from different language backgrounds, i.e. Dutch or French. In this test, we did not use a name-based allocation for language allegiance, but rather one based on the immigrants' parishes of origin. The majority language in a parish was taken from research by De Coussemaker from the 1850s (reported in Ryckeboer, 2000: 90). This data is some 200 years more recent than ours, and as the language shift in the area had been progressing slowly over these centuries, with increasing proportions of French speakers in communities across the region, the number of majority French-language parishes is probably slightly overestimated. In addition, and more importantly, the majority language in a community need not have any bearing on the preferred language of an individual. Despite this, some interesting patterns do emerge from our data.

Table 2 shows the distribution of immigrants by majority language in their parish of origin. Of the 168 immigrants in the data, 122 are from parishes where Dutch was the majority language, and 45 were from French-speaking parishes. (The remaining immigrant was from Lübeck, Germany. He has been excluded from any further analyses.) The ratio of Dutch- to French-language origins for the immigrants is the same for both genders and both years, at approximately 3 to 1 . 
Table 2. Immigration patterns based on majority language in the parish of origin.

$\begin{array}{lrrrc}\text { Gender } & \text { Year } & \text { Dutch } & \text { French } & \text { Total count } \\ \text { Male } & 1647 & 67.3 \% & 30.9 \% & 55 \\ & 1657 & 77.1 \% & 22.9 \% & 35 \\ & \text { Both } & 71.1 \% & 28.0 \% & 90 \\ \text { Female } & 1647 & 75.0 \% & 25.0 \% & 52 \\ & 1657 & 73.1 \% & 26.9 \% & 26 \\ & \text { Both } & 74.4 \% & 25.6 \% & 78 \\ \text { Both } & 1647 & 71.0 \% & 28.0 \% & 107 \\ & 1657 & 75.4 \% & 24.6 \% & 61 \\ & \text { Both } & 72.6 \% & 26.8 \% & 168\end{array}$

The information about the majority language of immigrants' parishes of origin also offers an opportunity to assess the validity of the name-based language allocations used in the remainder of our analysis. Our two measures for language background, as expected, did not always agree, with $27 \%$ of immigrants showing a mismatch between the two measures. Despite the mismatch, the two measures show a moderate but significant correlation, and additional tests also suggest name-based language allocations are not a priori unreliable (Supp. Mat., Section 3). A possible interpretation of the mismatches is that it was exactly the mismatch between individual (name-based) and societal (locationbased) language preferences that encouraged migration, in particular for Dutch speakers from French-majority parishes, who may have migrated to Dunkirk to prevent language shift. In the absence of highly detailed demographic information on the individual parishes of origin, however, we cannot say to what extent migrants reflected the linguistic make-up of the population, and this interpretation of mismatches remains speculative.

\subsubsection{Migration Patterns by Geographical Provenance}

Using estimates by Vandewalle (1994: 65-111) of the development of the population of Dunkirk and the surrounding countryside, based on population registers and secondary indicators such as taxation records, we can track the steady urbanization of the area in the 17th century. The proportion of the population of the area living in Dunkirk grew from around $10 \%$ in the beginning of the 17 th century to $25 \%$ to $30 \%$ at the end of the century. The area's second town, Bergues, remained stable at around $10 \%$ of the population. Meanwhile, the rural hinterland saw a relative population decline from c. $80 \%$ 
to c. $60 \%$ to $65 \%$ of the population. (Vandewalle's data for the area's third town, Hondschoote, is more patchy and fluctuates heavily; these numbers have been included in the rural population here.) Combined with earlier findings of predominantly 'local,' i.e., short-distance, migration, we expected to find a majority of migrants to Dunkirk to originate from the town's direct surroundings.

Indeed, the migration as represented in the marriage registers is predominantly local, with the median distance (as the crow flies) from a migrant's parish of origin to Dunkirk slightly over $30 \mathrm{~km}$ (Supp. Mat., Section 2.2). The distance travelled by migrants from Dutch-speaking parishes is smaller than that travelled by migrants from French-speaking parishes, but this is due to the Dutch-French language border in De Coussemaker's data running approximately $20 \mathrm{~km}$ south of Dunkirk. The distance between the parish of origin and Dunkirk has no effect on the point pattern analysis suggests that there are no differences in migrant provenance for either gender or year (1647 or 1657).

It was striking that the vast majority of locations, whether in a majority Dutch- or French-speaking area, only supplied one single migrant to Dunkirk. The data we have analyzed is only a snapshot of two years, and a more complete longitudinal survey is necessary to shed more light, but this suggests that migration to Dunkirk was not a so-called 'chain migration,' where people migrate to a new location and join pre-existing social networks from their place of origin there. This fits the characterization of the migration to Dunkirk as local, as chain migrations usually take place over relatively longer distances.

\subsection{Migrants, Language, and Intermarriage}

The integration of immigrants into Dunkirk society was investigated by looking at patterns of intermarriage. As parishes of origin were not recorded in the data from 1667 onwards, we assigned all individuals in the data set a language allegiance on the basis of their names, as described above. To keep this measure consistent across all the years, we also used name-based language allegiances for the years 1647 and 1657, despite information about parishes of origin being available for that part of the data. The complete data set consists of approximately 1000 men and 1000 women, and the ratio of Dutchto French-language backgrounds is approximately 3 to 2 . There are very small numbers of other names: English, Italian, Swiss, and German.

We found a statistically significant bias towards same-language ('in-group') marriages, with mixed marriages stable across time at about a third of all marriages (Suppl. Mat., Section 4.1). However, due to the growing proportion of French speakers in this period, this stability hides an intensifying bias 
against mixed marriages in the period 1677-1697. The bias appears when the proportion of French speakers in the population approaches $40 \%$ for both genders. This same $40 \%$ threshold has been found in a similar study of crosslinguistic marriage patterns in Shetland (Knooihuizen, 2008).

To better understand what constraints there may have been on marriage in 17th-century Dunkirk society, we tested for a number of other factors the data offered information on, which may have influenced the integration of both language groups and the language shift to French, or may be indicative of such influences:

- The identity of the priests who recorded the marriage in the register, and who, according to the wording of the formula, also conducted the marriage ceremonies. This could indicate whether the two language groups were integrated or segregated in one of the most influential social institutions of the town.

- The literacy of the spouses. Literacy can be an (albeit imprecise) indicator of a person's educational level. As education at the time was a matter of access rather than aptitude, this indicator may show class divisions in the data. We do not see education or literacy as a prerequisite for the acquisition of French, which may just as well happen — and is very likely to have happened —in face-to-face contact with French speakers. (Data available for 1697 only.)

- The spouses' previous marriage status. This is not an indicator of age, but may indicate social status as well. Widow(er)s may have enjoyed a different status in society, which may have had an effect on their choice of marriage partner. This is likely to have been a negative change: marriage was often an economic necessity, even more so in the case of re-marriages (Dupâquier et al., 1988: 316).

- The spouses' status as an immigrant or Dunkirk local. This is the most obvious measure of the integration of migrants, regardless of language background. (Data available for 1647 and 1657 only.)

Detailed analyses are given in Suppl. Mat., Section 4. Here we will focus only on the interpretation of significant results with regard to priests, literacy, and previous marriage status.

For some of the most frequently occurring priests in our data, there is a statistically significant preference for monolingual Dutch and/or monolingual French marriages (Suppl. Mat., Section 4.2). This is not enough evidence to suggest that the Catholic parish of Dunkirk was in effect two parishes, separated by language, but it may have been possible to request to be married by a specific vicar, and this vicar's language skills and preferences may have played a role in this decision. In any case, it does not suggest an antagonistic repression of either of the two languages spoken in Dunkirk. 
Literacy seems to have been a non-negligible factor in the patterning of marriages (Suppl. Mat., Section 4.3), with a matching educational background being a more important criterion in partner choice than language background. Likewise, there is a small correlation between partners' previous marriage status (Suppl. Mat., Section 4.4), but this, too, has no influence on the rate of crosslanguage marriages.

Finally, partner choice across language boundaries in our data is not influenced by a person's status as an immigrant or a Dunkirk local. However, when we investigate the influence of immigrant status and (name-based) language background simultaneously, we do find a significant pattern: Dutch immigrant men in our data married fewer immigrant women (and more local women) than expected, and French immigrant men married more immigrant women than expected (Suppl. Mat., Section 4.5). This contrast is not due to different proportions of Dutch and French speakers among locals and immigrants, but holds regardless of the woman's language. A possible, but speculative, interpretation of this divide is that despite an important and growing role for French in Dunkirk, it was still easier for Dutch-speaking migrants to integrate with the local population.

\subsection{Conclusions about Migration and Integration in Dunkirk}

The immigration to Dunkirk for which evidence can be found in the 1647 and 1657 marriage registers was a local migration, dominated by Dutch speakers, and with men in a slight majority. The distance from Dunkirk to Frenchspeaking areas was slightly larger than to the town's Dutch-speaking hinterland, ${ }^{4}$ and therefore it is possible that this partly explains the minority of French speakers among the immigrants. The geographic background of the migrants is stable between 1647 and 1657, but given that the ratio of Dutch to French speakers in this part of the data set is 3 to 1 , but is 3 to 2 in the complete data set (1647-1697), the French population must have grown considerably since the annexation in 1662, presumably through immigration. As French-language migrants must have come from further away, this means that the nature of the migration may have changed as well. Unfortunately, because parish of origin was no longer mentioned in the marriage registers after the annexation, the data surveyed does not allow us to study this further.

\footnotetext{
4) We expect that the adoption of French occurred in larger urban centres before it spread to the surrounding countryside, in a pattern that is reminiscent of a gravity model of linguistic change (Britain, 2002: 624). At any given time during the shift, then, the position of French in Dunkirk will have been at a more advanced stage than in the surrounding rural communities, which in this period remained largely Dutch-speaking.
} 
Compared to the migration patterns found in Cabantous (1983), our preannexation data shows a similar degree of local migration, with approximately a third of immigrants coming from within $20 \mathrm{~km}$ of Dunkirk in both data sets. However, our data shows considerably less migration from regions further away, such as Central France and the rest of Europe, focusing instead more on French Flanders and adjacent areas in present-day (Belgian) Flanders. The growing proportion of French speakers in our data after the annexation suggests a shift to a pattern more like Cabantous'.

We found no difference in literacy between Dutch and French speakers, which presumably is indicative of a similar level of education in both groups, suggesting that the French immigrants were not an upper-class group imported to Dunkirk as a new élite, but rather that the two groups enjoyed equal social status. One would therefore think that there were no social barriers hampering their social integration or preventing intermarriage between both language groups.

However, the data shows a significant bias against intermarriage. If marriage patterns reflect circles of socialization, this means that the two groups were not fully integrated, and that there was some degree of segregation according to language. This bias seems to appear in the data only when the French-speaking group reaches a proportion of $40 \%$ in the population. Further research on similar cases will have to show whether we should attach meaning to this finding. (Another explanation could be a delayed effect of the start of the largerscale immigration which presumably set in at the time of annexation, 15 years before the bias appears.)

Priests' preferences in marriage type could also indicate some form of segregation. However, the fact that priests were able to conduct ceremonies for people with different language backgrounds suggests that they were individually bilingual. The occurrence of mismatches between location- and name-based assignments of language allegiance also suggests at least societal, but possibly also individual, bilingualism in the migrants' locations of origin.

The existence of possibly widespread bilingualism, combined with a bias against intermarriage in both groups, could be a reason why Dutch survived in French Flanders for another three centuries after the region's annexation by France. An extension of this research in time (to a longer period after the annexation), space (including different locations in French Flanders), and scope (including different types of population registers for cross-reference) would shed more light on this issue. 


\section{Language Shift and Language Spread}

The second part of our study focuses on regional language patterns in the early 20th century. Where most studies on minority language shift are presented as studies of language loss (e.g., Gal, 1979; Dorian, 1981), we choose here to present the shift not as a loss of Dutch from the community, but as the spread of French to and in the community. This allows us to focus on the target language in language shift and on its linguistic form, which may contain clues to processes that took place during its development.

Descriptions of target varieties in language shift often focus on possible substrate influences from the abandoned minority language (see, e.g., Hickey, 2007: esp. Chapter 4; Thomas, 1997; and Shuken, 1984, on the influence of Celtic on the English spoken in Ireland, Wales, and the Scottish Highlands and Islands). Language shift is generally preceded by a period of bilingualism, and in this period, when the target variety is spoken as an L2, it may be influenced by interference from non-native speakers' $\mathrm{L} 1$. These interference features may even be targeted as a model for acquisition, giving rise to a language-shift variety and later ethnolect of the target language. In the case of the Dutch-toFrench shift in Dunkirk, however, it is difficult to assess whether (supposed) Dutch interference in French is due to shift or to centuries-long language contact along the Germanic-Romance border, as is the case with, e.g., wordfinal consonant devoicing in Picard (e.g., sage [sa]], possible [pssip]; see Pooley, 1994, 2002).

Even if we were able to distinguish between shift-induced and contactinduced interference, a focus on language spread rather than language shift addresses other interesting issues. Most importantly, non-native speaker L1 interference has to affect something: what was the model the shifting speakers had for acquiring French? We established in the previous section that there was a reasonable level of education in Dunkirk among Dutch speakers, especially among the men, and we cannot rule out that Standard French served as a model for language acquisition for them. But just as much, their model may have been whatever variety of French was spoken by the native French speakers in Dunkirk-and depending on where these native speakers came from, this may not have resembled Standard French. As in similar, later, cases of Dutchto-French language shift in the north of France, the model may have been a form of Picard (Landrecies, 2001: 54; Pooley, 2006: 228; but see Pée and Blancquaert, 1946: ix), but as Pooley also notes, the shifters may have perceived Picard as a suitable model for the acquisition of 'French.'

In this section, we give a quantitative dialectological analysis of the variety of French that replaced Dutch in Dunkirk. By comparing this variety to different dialects of French, it may suggest what varieties of French may have been 
spoken in Dunkirk. The study has been designed to match our information about the provenance of French-speaking immigrants in the town (Section 3.3). This allows us to determine the influence of these immigrants' dialects on the town's French, and to present a combined sociohistorical and historical linguistic account of migration and language shift in Dunkirk.

\subsection{Methods}

For this study, we used a computational method of language comparison based on phonetic data. Phonetic form is a more useful measure of linguistic differences between dialects than lexical form, because we can expect extremely high proportions of shared cognates between dialects, with the more informative differences lying in their exact phonetic form. Several paradigms for phonetic comparison exist, the main differences consisting in data input methods and in the way results are visualized and interpreted.

Goebl (2010b: 437) distinguishes roughly between two methods for inputting data from a particular corpus, typically a linguistic atlas. The first of these he names the 'Salzburg approach' (e.g., Goebl, 2006), where data is coded for a large number of distinctive phonetic, morphological or lexical features. The alternative is the 'Groningen approach' (e.g., Heeringa, 2004), where atlas data is digitized and quantitative differences between items in different varieties are calculated automatically by means of the Levenshtein method.

The method used in our study, developed by Heggarty et al. (2005), is conceptually similar to the Groningen approach, but rather than using Levenshtein distances, this method compares individual pairs of segments with regard to a number of phonetic features. ${ }^{5}$ The overall similarity between two varieties, then, is the average similarity of all pairs of segments in the entire sample. The advantage of this measurement over Levenshtein distances is that it can capture fine phonetic detail without relying on multiple dimensions (Maguire and McMahon, 2011: 106-111).

It is essential in a phonetic comparison to compare like with like. Taking the word chemise 'shirt' as an example (Fig. 2), it is clear that a simple sequential comparison does not give the right picture of how similar varieties are. Rather we need to ensure that the [ts] and first [ə] in [tsəmizə] (Le Châble) are compared to the metathesized [k] and [e] in [ekmis] (Cagny), respectively, as

\footnotetext{
5) See Heggarty et al. (2005) for a detailed overview of the parameters used in this method, and McMahon et al. (2007) and Maguire et al. (2010) for practical applications of the method in contemporary dialectology. We thank Paul Heggarty for allowing us to use his software, and for his advice in preparing the data set for analysis. Further information about the software is available from Heggarty's website at http://www.soundcomparisons.com/.
} 
chemise 'shirt'

SLOTMATCHING FORM

\begin{tabular}{c|c|c|c|c|c|}
$\mathrm{k}$ & 2 & $\mathrm{~m}$ & $\mathrm{i}$ & $\mathrm{s}$ & 2 \\
\hline 1 & 2 & 3 & 4 & 5 & 6 \\
\hline
\end{tabular}

LE CHÂBLE

\begin{tabular}{l|l|l|l|l|l|l|l|}
$\mathrm{t}$ & $\mathrm{s}$ & 2 & $\mathrm{~m}$ & $\mathrm{i}$ & $\mathrm{z}$ & $\partial$ \\
\hline $\mathbf{1}$ & $\mathbf{1}$ & $\mathbf{2}$ & $\mathbf{3}$ & $\mathbf{4}$ & $\mathbf{5}$ & 6 \\
\hline
\end{tabular}

LE PLESSIS-PIQUET

\begin{tabular}{c|c|c|c|}
$\int$ & $\mathrm{m}$ & $\mathrm{I}$ & $\mathrm{Z}$ \\
\hline 1 & 3 & 4 & 5
\end{tabular}

CAGNY

\begin{tabular}{c|c|c|c|c|} 
e & $\mathrm{k}$ & $\mathrm{m}$ & $\mathrm{i}$ & $\mathrm{s}$ \\
\hline 2 & 1 & 3 & 4 & 5
\end{tabular}

Figure 2. Slot-matching ensures the right phonetic items are compared to each other.

they are historically derived from the same forms. This is done by linking all segments to slots in an artificial slot-matching form; although these forms were designed with historical linguistic changes in mind and roughly depict earlier French 'common ancestor' forms of the dialects in the study, the slot-matching forms have no basis in historical reality and serve only to match corresponding segments. The comparison is made through (and not to) this form. Figure 2 shows how some of the forms for chemise are linked to a slot-matching form.

The dialectometric comparison of varieties results in a matrix of similarity scores. For convenient further analysis, the data from the similarity matrix can be visualized in various ways (Maguire and McMahon, 2011: 111-116). The obvious representation for comparing geographically based variation is on maps-see Goebl (2006: 415-420; 2010b: 441-449) for a discussion of different types of maps. Because we are interested here in similarities between varieties regardless of geographic location, which may be obscured exactly by forcing geography onto the visualization, we have chosen instead to visualize the similarity matrix more abstractly as a network. The network representation clearly indicates major divisions in the data set, represented by a series of larger rectangles. Moreover, networks allow non-regional groupings of varieties, as the position of a variety in a network depends not on geography but on the linguistic distance to other varieties in the sample. Network representations also have a distinct advantage over traditional visualizations as trees: where trees force varieties to be placed in specific branches of a tree, even when there may not be a great deal of evidence in favor of one group- 
ing over another, networks show all likely groupings at the same time. (See McMahon et al., 2007: 130-133 for a more in-depth discussion of networks and trees.) Our study used NeighborNet (Bryant and Moulton, 2004) for tree drawing.

Quantitative dialectological methods are of course suitable for comparing data from two different periods diachronically (see, e.g., Goebl, 2008), but in our study we are comparing data synchronically. It is therefore important to note that the comparisons may not say anything conclusive about the diachronic developments of varieties (McMahon and McMahon, 2008: 277). They may, however, expose patterns that traditional dialectology might miss (McMahon et al., 2007: 116; see also Maguire et al., 2010); the explanation for such patterns may well lie in a historical development (e.g., Goebl, 2010a: 71).

We underline again that this section takes synchronic patterns as a starting point, especially as similar methods are also used in historical reconstruction (e.g., McMahon and McMahon, 2005; Dunn et al., 2008; Greenhill et al., 2010). Those studies interpret apparently similar visual representations (trees and networks connecting languages or dialects) as showing historical relationships between these languages. In our study, we take the visual representations to show the patterning of synchronic similarity between dialects as quantified by the specific measures used in this paper. This synchronic similarity is likely to be the product of diachronic processes, but the connection between a network as the visual representation of this pattern and the historical processes that produced it might not be simple and linear. Therefore, we prefer not to interpret these visual representations as depictions of historical processes except at the coarsest level.

\subsection{Sources and Data}

Data for this study was taken from two dialect atlases: the Atlas Linguistique de la France (ALF, Gilliéron and Edmont, 1902-1915) and, to allow for a geographically more fine-grained analysis, the more local Atlas Linguistique et Ethnographique Picard (ALPic, Carton and Lebègue, 1989, 1997). This meant large amounts of comparable data could be collected rapidly. The use of atlas data is sometimes criticized because the quality of the data is out of the researcher's control: although information on the identity, and sometimes social background, of informants and interviewers is generally available, we do not know to what extent any idiosyncrasies may have influenced the data. However, atlas data has been used successfully in quantitative dialectological studies, with the results complying with traditional dialect classifications (Heeringa, 2004: 213-226). 
Locations for which data was used in the comparison were selected nonrandomly. ALPic shows French Flanders as a large white space marked 'Flandre,' and ignores any Romance dialect that may have been the majority language of the area when the data was collected from the 1960s onwards. ALF does have one location in French Flanders: Fort-Mardyck (ALF point 297), a fishing village that has now been absorbed by Dunkirk. We will consider the variety from Fort-Mardyck to be representative of 'Dunkirk' dialect in this study.

Other locations were picked to be as close a match as possible to the places of origin of immigrants to Dunkirk in 1647-1657, although due to the spread of ALF and ALPic survey locations, it was not possible to get a complete match. We included locations (a) on the Northern periphery of the Picard dialect continuum, as this was where the majority of French-speaking immigrants before 1662 came from; and (b) near larger urban centers in Picardy and France, as other possible sources of immigration after 1662. We also included modern-day Standard French, and one variety each of Occitan and Swiss French as controls. Four locations occurring in both ALF and ALPic were included to check the compatibility of the data from both atlases. A complete list of locations used in the study, including ALF and ALPic atlas references, is given in Table 3.

Table 3. Varieties included in the study, with references to survey points in ALF and ALPic. Single-letter codes given for these varieties are used in Fig. 4.

\begin{tabular}{lll}
\multicolumn{1}{l}{ Variety } & Atlas reference \\
- Fort-Mardyck & ALF 297 \\
a Coquelles & ALPic 1 \\
b Vieille-Église & ALPic 2 \\
c Tatinghem & ALPic 5 \\
d Ecques & ALPic 10 \\
e & Blaringhem & ALPic 11 \\
f Haverskerque & ALPic 12 \\
g & Erquinghem-Lys & ALPic 21 \\
h Prémesques & ALPic 14 \\
i Tubersent & ALPic 17 \\
j $\quad$ Linselles & ALF 295 / ALPic 15 \\
k Fampoux & ALPic 41 \\
l Bruille-Saint-Amand & ALF 281 / ALPic 35 \\
m Iwuy & ALPic 50 \\
n Maurois & ALF 271 / ALPic 63
\end{tabular}




$\begin{array}{lll} & \text { Variety } & \text { Atlas reference } \\ \text { o } & \text { Glageon } & \text { ALF 270 / ALPic 66 } \\ \text { p } & \text { Cagny } & \text { ALPic 88 } \\ \text { q } & \text { Bresles } & \text { ALPic 124 } \\ \text { r } & \text { Bourguignon-sous-Montbavin } & \text { ALPic 127 } \\ \text { s } & \text { Le Plessis-Piquet } & \text { ALF 226 } \\ \text { t } & \text { Verzenay } & \text { ALF 148 } \\ \text { u } & \text { Nibelle-Saint-Sauveur } & \text { ALF 209 } \\ \text { v } & \text { Cahors } & \text { ALF 720 } \\ \text { w } & \text { Le Châble } & \text { ALF 977 } \\ \text { x } & \text { Standard French } & -\end{array}$

For each of these locations, we collected the realizations for sixty lexical items. ${ }^{6}$ About half of these were picked because they could show salient differences between Picard and French (Pooley, 2002: 38), the other half was selected randomly. For compatibility with Heggarty's software, the ALF and ALPic transcriptions were converted to IPA following the guidelines in Dawson (2006: 101). The transcriptions were then slot-matched in a semi-automated procedure with manual proofreading and correction, after which the distance matrix was computed.

\footnotetext{
6) The lexical items analyzed in the study, with reference to the relevant ALF and ALPic maps, are: agneau (ALF 11, ALPic 183), aiguille (ALF 14, ALPic 459), arbres (ALF 52, ALPic 239 arbre), armoire (ALF 58, ALPic 381), bouf (ALF 141, ALPic 161), cendres (ALF 210, ALPic 359), chaîne (ALF 221, ALPic 156), champs (ALF 226, ALPic 96), charpentier (ALF 244, ALPic 300), chand (ALF 254, ALPic 320), chemise (ALF 264, ALPic 450), cheval (ALF 269, ALPic 158), chien (ALF 277, ALPic 188), cimetière (ALF 288, ALPic 570), copeaux (ALF 319, ALPic 291), coude (ALF 330, ALPic 471), couteau (ALF 341, ALPic 307), coutre (ALF 1523, ALPic 109), enfant (ALF 461, ALPic 488), ensemble (ALF 464, ALPic 658), essieu (ALF 484, ALPic 81), était (ALF 510, ALPic 15), étions (ALF 512, ALPic 640), faucille (ALF 543, ALPic 126), faux (ALF 546, ALPic 119), feu (ALF 558, ALPic 405), feuille (ALF 559, ALPic 241), frisson (ALPic 519), génisse (ALF 637, ALPic 163), grenouille (ALF 668, ALPic 227), herse (ALF 689, ALPic 103), jarretières (ALF 714, ALPic 452), jeunes (ALF 722, ALPic 489 jeune), lui (ALF 784, ALPic 631), maçon (ALF 791, ALPic 311), maison (ALF 801, ALPic 494), mangé (ALF 809, ALPic 494 manger), moi (ALF 863, ALPic 16), Noël (ALF 914, ALPic 362), noyau (ALF 926, ALPic 273), auf (ALF 935, ALPic 209), orage (ALF 945, ALPic 334), pain (ALF 964, ALPic 424), pas/point (the negator; ALF 896, ALPic 652), pigeon (ALF 1016, ALPic 218), poireau (ALF 1048, ALPic 262), poisson (ALF 1052, ALPic 226), puits (ALF 1104, ALPic 51), re- (ALF 1138 reculer, ALPic 463 repriser), roitelet (ALF 1697, ALPic 584), roue (ALF 1170, ALPic 80), sac (ALF 1336, ALPic 461), semaine (ALF 1214, ALPic 352), soleil (ALF 1241, ALPic 318), son (ALF 316, ALPic 13), table (ALF 1273, ALPic 384), trou (ALF 1336, ALPic 461), vache (ALF 1349, ALPic 162), veau (ALF 1354, ALPic 164), and voir (ALF 1408, ALPic 502).
} 


\subsection{Results and Discussion}

Comparing the ALF and ALPic data (Suppl. Mat., Section 5.1) shows that although the varieties did change over time, they remained more similar to their old selves than they became to any other variety. We therefore believe that a comparison of ALF data for Fort-Mardyck to ALPic data is justified.

The dialect of Fort-Mardyck is more similar to Picard varieties than it is to (more standard-like) French varieties and, within Picard, the geographically nearby locations tend to have higher similarity scores than those further from Fort-Mardyck (Table 4). The same patterns can be seen when exploring the entire data set, visualized as a network. A network based on all similarity scores between varieties in our study is shown in Fig. 3, drawn using NeighborNet (Bryant and Moulton, 2004); Fort-Mardyck can be found on the right-hand side of the network.

Table 4. Similarity scores between Fort-Mardyck and the other varieties in the sample, ranked in order of similarity.

$\begin{array}{llll}\text { Location } & \text { Score } & \text { Location } & \text { Score } \\ \text { Coquelles } & 0.870 & \text { Glageon (ALF) } & 0.787 \\ \text { Tatinghem } & 0.856 & \text { Prémesques } & 0.784 \\ \text { Blaringhem } & 0.822 & \text { Glageon (ALPic) } & 0.780 \\ \text { Ecques } & 0.816 & \text { Iwuy } & 0.777 \\ \text { Haverskerque } & 0.807 & \text { Maurois (ALPic) } & 0.776 \\ \text { Cagny } & 0.803 & \text { Nibelle-Saint-Sauveur } & 0.768 \\ \text { Maurois (ALF) } & 0.802 & \text { Le Plessis-Piquet } & 0.767 \\ \text { Fampoux } & 0.801 & \text { Standard French } & 0.765 \\ \text { Vieille-Église } & 0.800 & \text { Bruille-Saint-Amand (ALPic) } & 0.765 \\ \text { Bruille-Saint-Amand (ALF) } & 0.796 & \text { Bourguignon-sous-Montbavin } & 0.762 \\ \text { Tubersent } & 0.795 & \text { Verzenay } & 0.751 \\ \text { Bresles } & 0.794 & \text { Linselles (ALPic) } & 0.748 \\ \text { Linselles (ALF) } & 0.790 & \text { Le Châble } & 0.590 \\ \text { Erquinghem-Lys } & 0.788 & \text { Cahors } & 0.548\end{array}$

The network representation clearly indicates major divisions in the data set, represented by a series of larger rectangles. The clearest division in the network is the one setting apart the top left-hand quarter from the rest. Based on the varieties in each group, this is probably a split between Francien (Standard French-like) varieties in the top left, and Picard varieties towards the bottom right. Fort-Mardyck clearly belongs to the Picard group, as the similarity scores already suggested. 


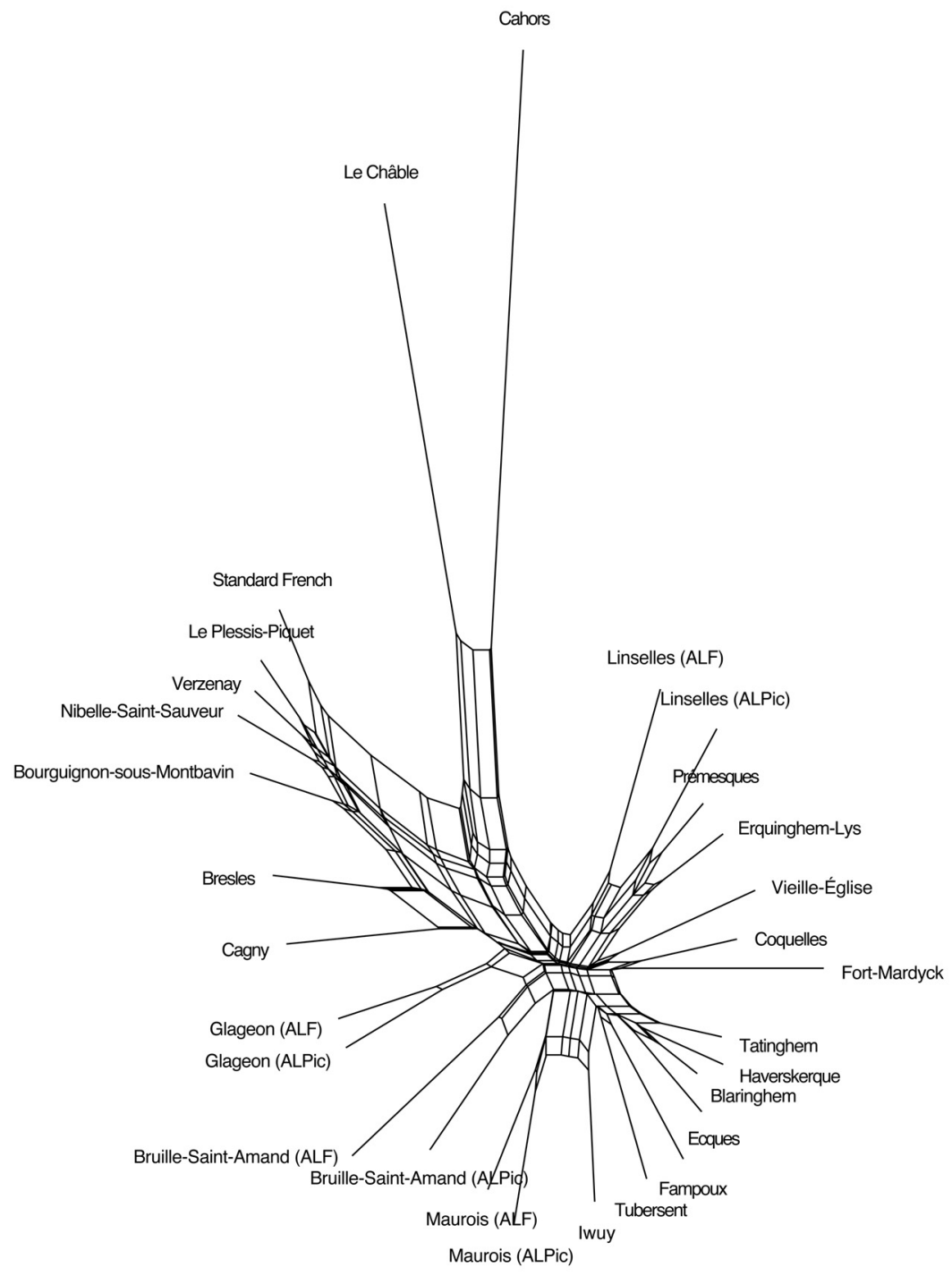

Figure 3. Similarity between the varieties in the data set expressed as a network. 


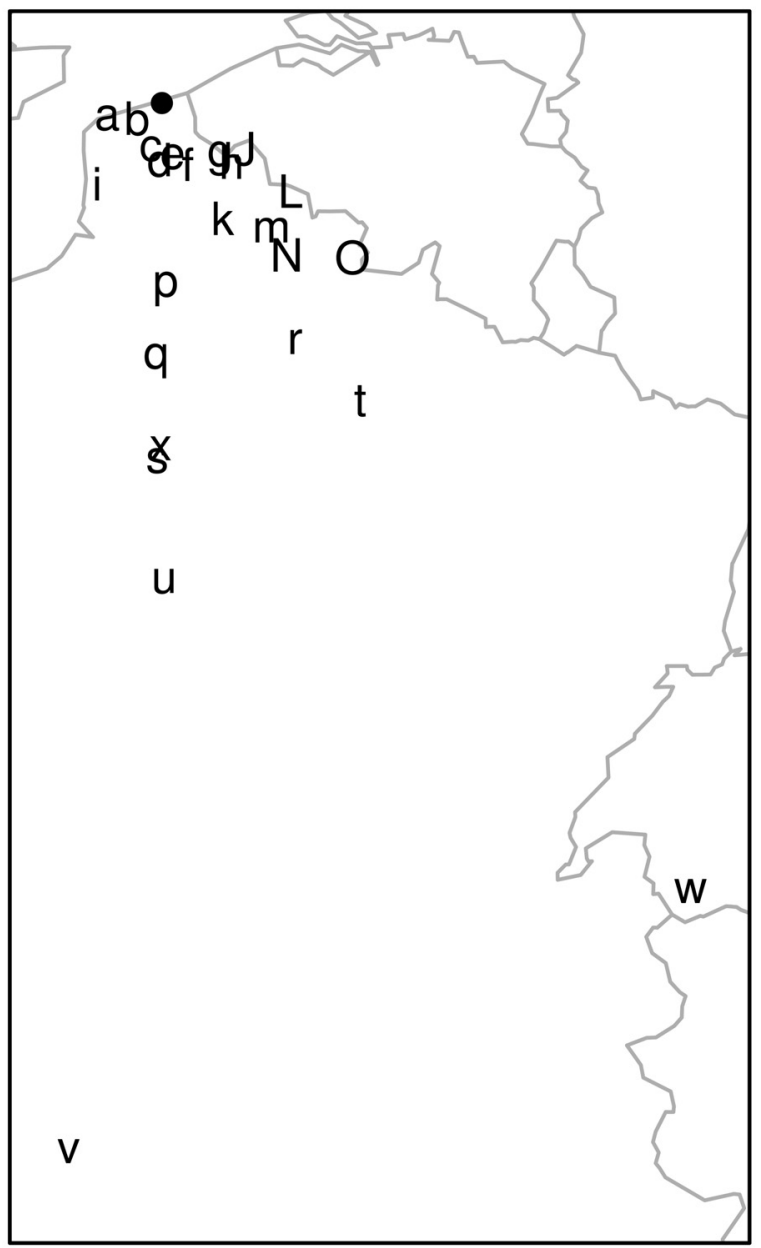

Figure 4a. Geographic locations of the varieties used in the sample. See Table 3 for a legend; capital letters denote ALF data for locations for which both ALF and ALPic data was used.

Within Picard, we can see three clusters: a Northern group, with Linselles, Prémesques, and Erquinghem-Lys; a looser North-Eastern group, with Glageon, Bruille-Saint-Amand, and Maurois; and a group with North-Western and Central Picard varieties, with Fampoux, Ecques, Blaringhem, Haverskerque, and Tatinghem. Fort-Mardyck, with the geographically close varieties from Coquelles and Vieille-Église, seems to be intermediate between the Northern and the North-West-Central groups. This is where we would geographically expect it to be, perhaps, but also note that Fort-Mardyck is pulled 


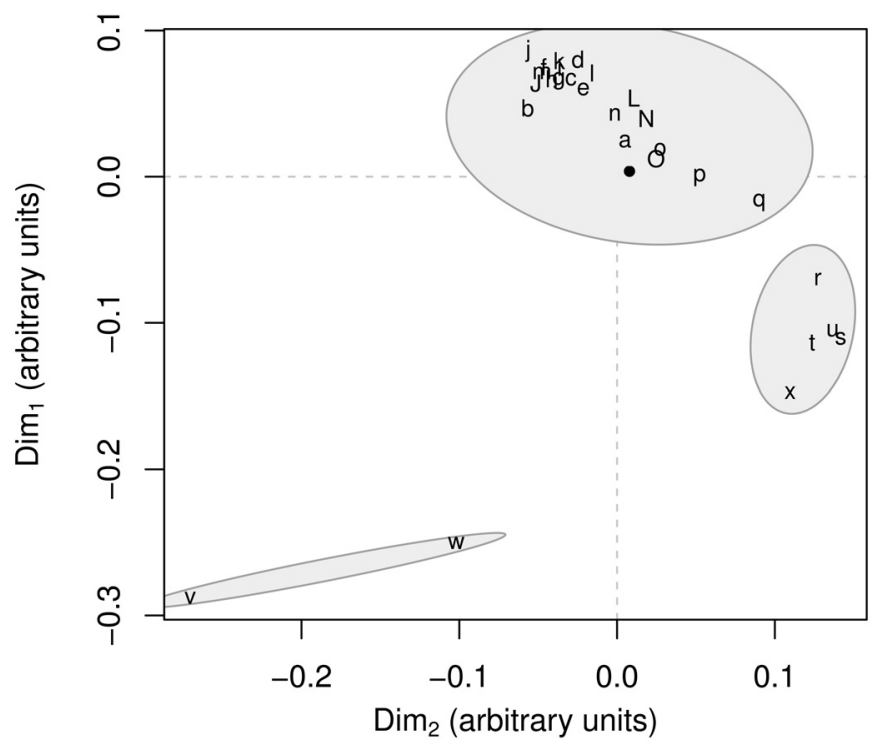

Figure 4b. Multidimensional scaling of the linguistic distances between the varieties used in the sample.

more towards the North-West-Central group than Coquelles and VieilleÉglise, which are geographically closer. This could perhaps be a consequence of the immigration of Picard speakers from this area in particular; see also the Central Picard variety of Cagny, which in the network is on a branch directly opposite from Fort-Mardyck, with a relatively high similarity score of 0.803 .

Representing the distances between varieties using Multidimensional Scaling (MDS, see Suppl. Mat., Section 5.2) allows us to compare their relative positions within this abstract "linguistic" space with their positions in the real geographical space (Fig. 4, a and b) and to identify any relationships between geography and linguistics. Figure $4 \mathrm{c}$ shows a visual representation of the similarities between varieties as a tree (see Suppl. Mat., Section 5.2, for details and interpretation), which, crucially, is not intended to represent the historical relationships between these varieties, but only their similarities.

These two techniques do not agree perfectly (Suppl. Mat., Section 5.2) but they do reinforce each other in suggesting a similar broad scenario. Both identify the two outliers Cahors (Occitan, $v$ ) and Le Châble (Swiss French, $w$ ), and the cluster of Standard French-like varieties spoken in the Paris area: Bourguignon-sous-Montbavin $(r)$, Le Plessis-Piquet $(s)$, Verzenay $(t)$, NibelleSaint-Sauveur $(u)$, and Standard French itself $(x)$. As in the NeighborNet analysis, Fort-Mardyck, represented in Fig. 4 by a black dot, is clearly placed 


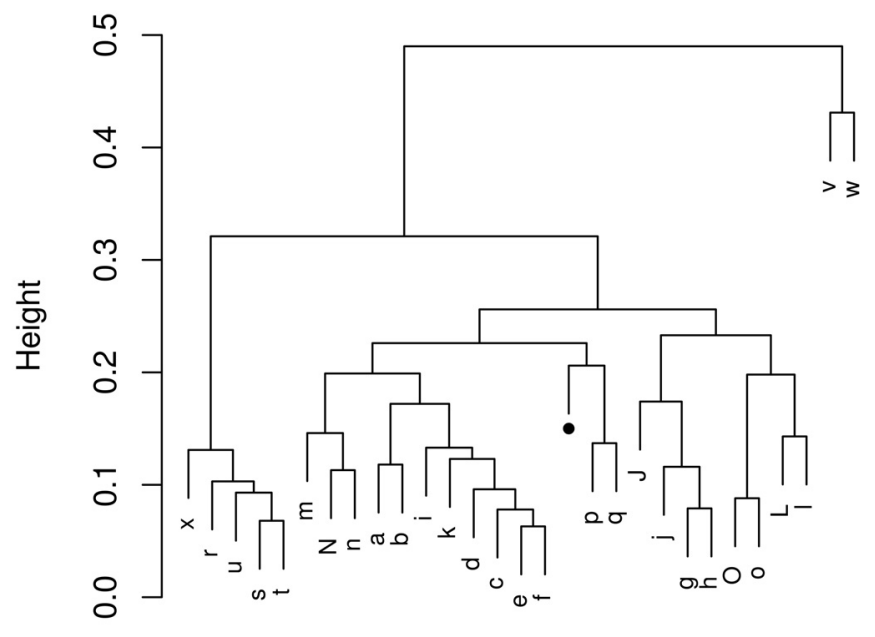

Clusters

Figure 4c. Hierarchical clustering of the linguistic distances between the varieties used in the sample.

within the Picard cluster; within Picard, the variety does not cluster with its immediate geographical neighbours, but shows stronger affiliations with varieties relatively further away-Cagny $(p)$, Bresles $(q)$, Glageon $(o, O)$, and Maurois $(n, N)$-and is 'attracted' towards Standard French (see Fig. $4 \mathrm{~b}$ ). Again, the clustering of corresponding varieties from both data sources suggests the atlas data is compatible.

Correlations between geographical and linguistic distances (Suppl. Mat., Section 5.2) show that, in general, varieties further away tend to be more different from each other, but also suggest that factors other than geography play an important role. In particular, the Fort-Mardyck dialect fits neatly onto the dialect continuum in the area; but the remote varieties Cahors and Le Châble are identified as being linguistically more divergent from FortMardyck than expected, and Tatinghem and Coquelles as being even more similar than expected based on their close geographical proximity to FortMardyck.

In these quantitative analyses, Fort-Mardyck emerges as an unambiguously Picard variety, although the details vary between analyses. Because our values for linguistic distance are unidimensional representations of a complex reality - sixty words with multiple segments that may differ along several phonetic parameters as well as linear order-we can expect different analyses to provide different perspectives on this multidimensional pattern. We must 
therefore focus primarily on broad similarities between the analyses rather than on differences in detail, although these, too, can be informative. Multidimensional scaling grouped the variety together with Central Picard (Cagny and Bresles) rather than geographically closer peripheral varieties, while the correlation of linguistic and geographical distances gives a good fit, with the two geographically closest varieties more similar to Fort-Mardyck than they should be given their geographical distances. The NeighborNet analysis sees similarities with varieties both nearby and further away. It seems safe to conclude that although Fort-Mardyck is a Picard variety, there are other influences on the dialect. A qualitative analysis of the Fort-Mardyck realizations may shed more light on the nature of these influences; we restrict ourselves here to a few initial observations.

The realization in Fort-Mardyck French of salient Picard features identified by Pooley (2002: 38) shows a clear split between phonological and morphosyntactic features. The morphosyntax of Fort-Mardyck French shows consistent Picard influence, e.g. in the imperfect ending, possessive and personal pronouns, the reiterative prefix and the negator. The phonology, on the other hand, shows considerable variability in both vocalic and consonantal phonology: some words are realized with Picard features, others with French ones. There are also some items that suggest hypercorrection-for example, the $[\mathrm{s}]$ in chemise [səmrz] 'shirt' and the [z] in orage [orazz] 'storm' may be related to the regular correspondence of French [s] to Picard [s] (e.g., maçon [ma55] 'mason') — but we would need additional data to determine whether this is idiolectal or part of the traditional dialect. If these are indeed examples of hypercorrection, they would suggest some awareness of the systematic differences between Picard and French.

\subsection{Conclusions about the Development of Fort-Mardyck French}

Both the quantitative and the qualitative comparative analyses of the FortMardyck dialect are synchronic: they show where the dialect stands in relation to other dialects of the same area around the beginning of the 20th century. The analyses cannot give direct information about the historical development of these varieties, and we have to rely on our knowledge of dialect contact, especially in situations of large-scale migrations (Trudgill, 1986, 2004), to make inferences. The atlas data therefore merely allows us to make suggestions as to how the dialect may have formed.

The picture of Fort-Mardyck French that emerges from the dialect atlas data is one of an essentially Picard and non-standard variety, suggesting that the dialect was acquired by Dutch speakers in informal, face-to-face contact with native speakers of these dialects, rather than in an institutional setting where a 
more standard-like variety would have been a more likely target. In particular, Fort-Mardyck French is similar to varieties from its direct vicinity and to those from Central Picardy. We may interpret this as evidence that these were the varieties people in Dunkirk were in contact with. It is not surprising that Dunkirk was in contact with its hinterland, and given the migration links to the local area and to Central Picardy, the linguistic similarities can be explained completely by the demographic evidence.

On the other hand, we cannot ignore the presence of some standard features in Fort-Mardyck French, and possibly even hypercorrections. These suggest that there was at least some awareness of Standard French, and of how Standard French differed from the Picard spoken in the area. We can therefore not rule out that Standard French was targeted at least by some speakers-by shifters when they formed the dialect, or by ALF informants when the data was collected. Although a detailed history of the dialect cannot be written on the basis of this data alone, we do believe we have shown the important role of migrant varieties in the development of Fort-Mardyck French.

\section{Conclusion: Migration and Language Shift}

We began this paper by opposing the study of language histories 'from above,' focusing on larger social and political developments, with that 'from below,' where the aim is to get as close to the individual historical speaker as the surviving data allows. Coming from the latter research paradigm, we suggested that proscriptive language policies, although they will have played a role, are not a sufficient explanation for language shift in the early modern period, and that demographic developments — the migration of majority-language speakers to minority-language areas-were a significant factor as well. Data from two studies of the Dutch-to-French language shift in 17th-century Dunkirk was presented in order to analyze the social and linguistic processes underlying language shift.

The first of our studies focused on the historical demography of Dunkirk around the time of the town's annexation to France in the second half of the 17 th century. In the first part of this study, we analyzed the origin of migrants to Dunkirk in the years prior to the annexation. The vast majority of migrants came from the local area, both majority Dutch- and French-speaking parts of French Flanders and the Spanish Netherlands, although Dutch-speaking migrants appear to have been in a majority. In later years, the balance seems to have shifted slightly in favor of more French-speaking migrants, but the available data was not sufficient to analyze this in greater detail.

The second part of the demographic study focused on the integration of the Dutch- and French-speaking population of Dunkirk, migrants as well as 
locals, by charting patterns of inter-group marriage. In the earlier part of the data, language does not seem to have been a factor in partner choice; a bias against cross-language marriages appears in the later part of the data, when the French population of Dunkirk amounts to some $40 \%$ of the population. Despite this bias, still around a third of all registered marriages was between partners of different language backgrounds. This pattern is found regardless of people's literacy, immigration or previous marriage status.

The second study was a linguistic analysis of the dialect of French spoken in Dunkirk. This was primarily a quantitative phonetic comparison of the Dunkirk dialect to a number of other relevant local and non-local dialects, augmented with a brief qualitative discussion. It emerges from this study that Dunkirk is Picard-speaking, which suggests an informal way of language learning in face-to-face contact, although there is some evidence of awareness of Standard French. Quantitatively, Dunkirk French is most similar to geographically nearby varieties, and to varieties from Central Picardy.

In broad terms, then, our migration study, supported by the linguistic analysis of Dunkirk French, constitutes evidence 'from below' of how French spread to Dunkirk. The integration study gives additional information of how French, once in Dunkirk, spread through the community, with inter-group marriage both a motive and a mechanism for acquisition of French. Statistical preferences, of course, do not exist in a vacuum, and the broader social and political developments stressed in an 'above' account play a role in, for example, defining sociolinguistic prestige or even instigating the very migration movements we have analyzed. At the same time, however, and despite problems with data and interpretation, our 'below' account of immigration, integration and language shift adds valuable detail to our understanding of Dunkirk's linguistic history.

At present, our study is an isolated example of an integrated 'below' account of language shift in one early modern community, and it remains to be seen to what extent our findings about the language shift processes induced by migration to Dunkirk are representative of language shift in this period in general. The survival of a large amount of documentary evidence in French Flanders will allow for our study to be put in the necessary context by adding linguistic and ethnographic detail based on personal documents. At the same time, comparing our results to historical demographic and linguistic evidence from other relevant communities will establish the role that purely demographic factors played in language shift in the early modern period. Similarities between our findings and those from a study of the Norn-to-Scots language shift in Shetland and the origins of Shetland Scots (Knooihuizen, 2008, 2009) suggest there are common sociolinguistic patterns in shift that further research taking a 'from below' approach will be able to help uncover. 


\section{Online Supplementary Materials}

We have prepared online supplementary materials in which we describe the statistical and computational methods used in this paper, and offer additional data, analysis and results. These supplementary materials can be downloaded at http://dx.doi.org/10.1163/221058212X653067.

\section{Acknowledgements}

This paper is largely based on Remco Knooihuizen's Ph.D. research at the University of Edinburgh, for which we gratefully acknowledge a (fees-only) grant for doctoral study from the Arts and Humanities Research Council (AHRC). Dan Dediu thanks the Economic and Social Research Council (ESRC) for a postdoctoral fellowship award held during the research leading to this paper. We would like to thank Mercedes Durham, Adam Fox, Paul Heggarty, Daniel Ezra Johnson, April McMahon, Warren Maguire, Pieter Seuren, Peter Trudgill, Alexandra Dima, conference audiences in Bristol and Nijmegen, and the Language Dynamics and Change reviewers and editor for their helpful comments and advice during various stages of the preparation of this paper.

\section{References}

Allardt, Erik. 1984. What constitutes a language minority? Journal of Multilingual and Multicultural Development 5: 195-205.

Bellingham, Roger A. 1990. The use of marriage horizons to measure migration: Some conclusions from a study of Pocklington, East Yorkshire in the late eighteenth century. Local Population Studies 44: 52-55.

Boulard, Gilles. 1999. L'ordonnance de Villers-Cotterêts: Le temps de la clarté et la stratégie du temps (1539-1992). Revue historique 609: 45-100.

Brankačk, Jan and Frido Mětšk (eds.). 1977. Geschichte der Sorben. Band I: Von den Anfängen bis 1789. Bautzen: Domowina.

Britain, David. 2002. Space and spatial diffusion. In J.K. Chambers, Peter Trudgill, and Natalie Schilling-Estes (eds.), The Handbook of Language Variation and Change, 603-637. Oxford: Blackwell.

Broderick, George. 1999. Language Death in the Isle of Man: An Investigation into the Decline and Extinction of Manx Gaelic as a Community Language in the Isle of Man. Tübingen: Niemeyer.

Bryant, David and Vincent Moulton. 2004. NeighborNet: An agglomerative algorithm for the construction of planar phylogenetic networks. Molecular Biology and Evolution 21: 255-265.

Burke, Peter. 2004. Languages and Communities in Early Modern Europe. Cambridge: Cambridge University Press.

Cabantous, Alain (ed.). 1983. Histoire de Dunkerque. Toulouse: Privat.

Carton, Fernand and Maurice Lebègue (eds.). 1989, 1997. Atlas linguistique et ethnographique picard, volumes 1 and 2. Paris: Éditions du Centre National de la Recherche Scientifique.

Coornaert, Émile. 1970. La Flandre française de langue flamande. Paris: Éditions Ouvrières. 
Dawson, Alain. 2006. Variation phonologique et cohésion dialectale en picard: Vers une théorie des correspondances dialectales. PhD dissertation, Université de Toulouse II-Le Mirail.

Debrabandere, Frans. 2003. Woordenboek van de familienamen in België en Noord-Frankrijk. Amsterdam/Antwerpen: Veen.

Donaldson, Gordon. 1983. The Scots settlement in Shetland. In Donald J. Withrington (ed.), Shetland and the Outside World 1469-1969, 8-19. Oxford: Oxford University Press.

Dorian, Nancy C. 1981. Language Death: The Life Cycle of a Scottish Gaelic Dialect. Philadelphia: University of Pennsylvania Press.

Dunn, Michael, Stephen C. Levinson, Eva Lindström, Ger Reesink, and Angela Terrill. 2008. Structural phylogeny in historical linguistics: Methodological explorations applied in Island Melanesia. Language 84: 710-759.

Dupâquier, Jacques et al. (eds.). 1988. Histoire de la population française. Tome 2: De la Renaissance à 1789. Paris: Presses Universitaires de France.

Elspaß, Stephan. 2005. Sprachgeschichte von unten: Untersuchungen zum geschriebenen Alltagsdeutsch im 19. Jahrhundert. Tübingen: Niemeyer.

Fellows-Jensen, Gillian. 1968. Scandinavian Personal Names in Lincolnshire and Yorkshire. København: Akademisk forlag.

Gal, Susan. 1979. Language Shift: Social Determinants of Linguistic Change in Bilingual Austria. New York: Academic Press.

Gilliéron, Jules and Edmond Edmont (eds.). 1902-1915. Atlas linguistique de la France. Paris: H. Champion.

Goebl, Hans. 2006. Recent advances in Salzburg dialectometry. Literary and Linguistic Computing 21: 411-435.

Goebl, Hans. 2008. Sur le changement macrolinguistique survenu entre 1300 et 1900 dans le domaine d'Oil: Une étude diachronique d'inspiration dialectométrique. Dialectologia 1: 343.

Goebl, Hans. 2010a. Dialectometry: Theoretical prerequisites, practical problems, and concrete applications (mainly with examples drawn from the 'Atlas Linguistique de la France', 19021910). Dialectologia. Special Issue 1: 63-77.

Goebl, Hans. 2010b. Dialectometry and quantitative mapping. In Alfred Lameli, Roland Kehrein, and Stefan Rabanus (eds.), Language and Space: An International Handbook of Linguistic Variation. Volume 2: Language Mapping, 433-457, 2201-2212. Berlin: De Gruyter.

Goris, Jean-Marie. 2004. La francisation à Dunkerque du temps de Jean Bart. Revue historique de Dunkerque et du littoral 37: 331-344.

Greenhill, Simon J., Quentin D. Atkinson, Andrew Meade, and Russell D. Gray. 2010. The shape and tempo of language evolution. Proceedings of the Royal Society B 277, 2443-2450.

Heeringa, Wilbert J. 2004. Measuring Dialect Pronunciation Differences Using Levenshtein Distance. $\mathrm{PhD}$ dissertation, Rijksuniversiteit Groningen.

Heggarty, Paul, April McMahon, and Rob McMahon. 2005. From phonetic similarity to dialect classification: A principled approach. In Nicole Delbecque, Johan van der Auwera, and Dirk Geeraerts (eds.), Perspectives on Variation: Sociolinguistic, Historical, Comparative, 43-91. Berlin: Mouton de Gruyter.

Hickey, Raymond. 2007. Irish English: History and Present-day Forms. Cambridge: Cambridge University Press.

Jenkins, Geraint H., Richard Suggett, and Eryn M. White. 1997. The Welsh language in early modern Wales. In Geraint H. Jenkins (ed.), The Welsh Language before the Industrial Revolution, 45-122. Cardiff: University of Wales Press.

Knooihuizen, Remco. 2008. Inter-ethnic marriage patterns in late sixteenth-century Shetland. Local Population Studies 80: 22-38.

Knooihuizen, Remco. 2009. Shetland Scots as a new dialect: Phonetic and phonological considerations. English Language and Linguistics 13: 483-501. 
Kunze, Peter. 1999. Zur brandenburgisch-preußischen Sorben-(Wenden-)Politik im 17. und 18. Jahrhundert. Lètopis 46: 3-15.

Landrecies, Jacques. 2001. Une configuration inédite: La triangulaire français-flamand-picard à Roubaix au début du XXe siècle. Langage et société 97: 27-69.

Lemercier, Claire and Paul-André Rosental. 2000. 'Pays' ruraux et découpage de l'espace: Les résaux migratoires dans la région lilloise au milieu du XIXe siècle. Population [French edition] 55: 691-726.

Levine, Gregory J. 1988. Class, ethnicity and property transfers in Montreal, 1907-1909. Journal of Historical Geography 14: 360-380.

Lomas, Kathryn. 2002. The polis in Italy: Ethnicity, colonization, and citizenship in the Western Mediterranean. In Roger Brock and Stephen Hodkinson (eds.), Alternatives to Athens: Varieties of Political Organization and Community in Ancient Greece, 167-185. Oxford: Oxford University Press.

Mac Giolla Chríost, Dairmait. 2005. The Irish Language in Ireland: From Goidel to Globalisation. London: Routledge.

Maguire, Warren, April McMahon, Paul Heggarty, and Dan Dediu. 2010. The past, present, and future of English dialects: Quantifying convergence, divergence, and dynamic equilibrium. Language Variation and Change 22: 69-104.

Maguire, Warren and April McMahon. 2011. Quantifying relations between dialects. In Warren Maguire and April McMahon (eds.), Analysing Variation in English, 93-120. Cambridge: Cambridge University Press.

Martel, Philippe. 2001. Autour de Villers-Cotterêts: Histoire d'un débat. Lengas 49: 7-25.

Mateos, Pablo. 2007. An Ontology of Ethnicity Based on Personal Names: With Implications for Neighbourhood Profiling. PhD dissertation, University College London.

McMahon, April and Rob McMahon. 2005. Language Classification by Numbers. Oxford: Oxford University Press.

McMahon, April and Rob McMahon. 2008. Genetics, historical linguistics and language variation. Language and Linguistics Compass 2: 264-288.

McMahon, April, Paul Heggarty, Rob McMahon, and Warren Maguire 2007. The sound patterns of English: Representing phonetic similarity. English Language and Linguistics 11: 113142.

Millard, Jeremy. 1982. A new approach to the study of marriage horizons. Local Population Studies 28: $10-31$.

Milroy, Lesley. 1987. Language and Social Networks. Oxford: Blackwell.

Pain, Andrew J. and Malcolm T. Smith. 1984. Do marriage horizons accurately measure migration? A test case from Stanhope parish, County Durham. Local Population Studies 33: 44-48.

Paulston, Christina B. 1986. Social factors in language maintenance and language shift. In Joshua A. Fishman (ed.), The Fergusonian Impact: In Honor of Charles A. Ferguson on the Occasion of his 65th Birthday, volume 2, 493-511. Berlin: Mouton de Gruyter.

Pée, Willem and Edgar Blancquaert. 1946. Dialect-atlas van West-Vlaanderen en Fransch-Vlaanderen, volume 1. Antwerpen: De Sikkel.

Pooley, Tim. 1994. Word-final consonant devoicing in a variety of working-class French: A case of language contact? Journal of French Language Studies 4: 215-233.

Pooley, Tim. 2002. The depicardization of the vernaculars of the Lille conurbation. In Mari C. Jones and Edith Esch (eds.), Language Contact: The Interplay of Internal, External and Extralinguistic Factors, 29-62. Berlin: Mouton de Gruyter.

Pooley, Tim. 2006. The linguistic assimilation of Flemish immigrants in Lille (1800-1914). Journal of French Language Studies 16: 207-233.

Poulain, Michel and Michel Foulon. 1981. L'immigration flamande en Wallonie: Évaluation à l'aide d'un indicateur anthroponymique. Belgisch Tijdschrift voor Nieuwste Geschiedenis = Revue belge d'histoire contemporaine (BTNG-RBHC) 12: 205-244. 
Poulain, Michel, Michel Foulon, Anna Degioanni, and Pierre Darlu. 2000. Flemish immigration in Wallonia and in France: Patronyms as data. The History of the Family 5: 227-241.

Ryckeboer, Hugo. 2000. The role of political borders in the millennial retreat of Dutch (Flemish) in the north of France. International Journal of the Sociology of Language 145: 79-108.

Ryckeboer, Hugo. 2002. Dutch/Flemish in the north of France. Journal of Multilingual and Multicultural Development 23: 22-35.

Ryckeboer, Hugo. 2004. Frans-Vlaams. Tielt: Lannoo.

Sharlin, Allan. 1978. Natural decrease in early modern cities: A reconsideration. Past \& Present 79: $126-138$.

Shuken, Cynthia R. 1984. Highland and Island English. In Peter Trudgill (ed.), Language in the British Isles, 152-166. Cambridge: Cambridge University Press.

Smith, Arthur S.D. 1947. The Story of the Cornish Language: Its Extinction and Revival. Camborne: Camborne Printing and Stationery Company.

Stevens, Gillian. 1985. Nativity, intermarriage, and mother-tongue shift. American Sociological Review 50: 74-83.

Stevens, Gillian and Gray Swicegood. 1987. The linguistic context of ethnic endogamy. American Sociological Review 52: 73-82.

Thomas, Alan R. 1997. The Welshness of Welsh English: A survey paper. In Hildegard L.C. Tristram (ed.), The Celtic Englishes, 55-85. Heidelberg: Winter.

Thomason, Sarah G. and Terrence Kaufman. 1991. Language Contact, Creolization, and Genetic Linguistics. Berkeley: University of California Press.

Trenard, Louis (ed.). 1972. Histoire des pays-bas français: Flandre, Artois, Hainaut, Boulonnais, Cambrésis. Toulouse: Privat.

Trudgill, Peter. 1986. Dialects in Contact. Oxford: Blackwell.

Trudgill, Peter. 2004. New-dialect Formation: The Inevitability of Colonial Englishes. Edinburgh: Edinburgh University Press.

Vandewalle, Paul. 1994. Quatre siècles d'agriculture dans la région de Dunkerque 1590-1990: Une étude statistique. Gent: Centre belge d'histoire rurale.

Vries, Oebele. 2001. Die Verdrängung des Altfriesischen als Schreibsprache. In Horst Haider Munske (ed.), Handbuch des Friesischen, 606-613. Tübingen: Niemeyer.

Webber, Richard. 2007. Using names to segment customers by cultural, ethnic or religious origin. Direct, Data and Digital Marketing Practice 8: 226-242.

Willemyns, Roland. 1997. Language shift through erosion: The case of the French-Flemish 'Westhoek'. Journal of Multilingual and Multicultural Development 18: 54-66.

Withers, Charles W.J. 1984. Gaelic in Scotland 1698-1981: The Geographical History of a Language. Edinburgh: Donald.

Withers, Charles W.J. 1988. Gaelic Scotland: The Transformation of a Culture Region. London: Routledge. 